\title{
Soil water storage variability in a three-dimensional analysis in the root zone of irrigated melon
}

Francisco Airdesson Lima do Nascimento ${ }^{1^{*}}$, Alisson Jadavi Pereira da Silva², Allan Radax Freitas Campos ${ }^{1}$

1. Universidade Federal do Recôncavo da Bahia - Núcleo de Engenharia de Água e Solo - Programa de Pós-Graduação em Engenharia Agrícola - Cruz das Almas (BA), Brazil.

2.Instituto Federal de Educação, Ciência e Tecnologia Baiano - Mangabeira (BA), Brazil

ABSTRACT: A detailed knowledge of the soil water storage variability in the root zone can promote recommendations regarding the ideal positioning of sensors, as well as make the calculation of soil water balance more precise and accurate. This study aimed to assess soil water storage variability in the melon root zone and indicate-based on spatial variation of soil water storage - the regions of highest root activity of the melon crop in different development stages. Soil water storage was measured using time domain reflectometry (TDR) in 40 monitoring points. The data were daily collected in two periods: (i) immediately before irrigation and (ii) $30 \mathrm{~min}$ after irrigation. The soil water storage variation in the melon root zone occurs with greater intensity throughout the time of vegetative growth and the highest values are always observed in the same distances and depths of the soil in all phases of growth. The region indicated as of greatest root activity of the melon crop under drip irrigation is delimited, in relation to the stem, by the radial distance of $0.36 \mathrm{~m}$ and depth of $0.3 \mathrm{~m}$, for all development stages.

Key words: soil water balance, drip irrigation, irrigation management. 


\section{INTRODUCTION}

Detailed understanding on the spatial-temporal variation of soil water storage in the root zone of crops can promote recommendations, as well as the effective root depth for water uptake, promoting accuracy in the irrigation depth calculation (Silva et al. 2015; Silva et al. 2018).

Applications of sustainable agricultural methodologies must take into consideration the biophysical process of water uptake by the crops (Green et al. 2006; Dabach et al. 2016). Knowledge about root system distribution can serve as a basis to recommend the positioning of sensors and application of nutrients (Sant'ana et al. 2012; Lucas et al. 2012). Nevertheless, studies reveal that there is not always a well-defined relationship between soil water storage distribution and root distribution (Silva et al. 2009; Raza et al. 2013; Silva et al. 2015).

Some recommendations for sensor positioning and application of nutrients based on the knowledge about the effective zones of soil water storage variation by plants have been made (Soulis et al. 2015; Soulis and Elmaloglou 2016), although these studies report that the knowledge about the soil water storage variations in the root zones of various crops is still of prime necessity.

Silva et al. (2015) considered the variation of soil water storage by the root system of banana trees without disregarding the evaporation in their measurements. However, aiming at the best accuracy and precision in the measurements, these authors monitored moisture variation in four monitoring profiles and four depths: $0.1,0.3,0.5$ and $0.7 \mathrm{~m}$.

Most studies on water movement towards plant roots focus on fruit crops (Coelho et al. 2010; Silva et al. 2015; Silva et al. 2018) and annual crops (Zarebanadkouki et al. 2012), and only a few studies deal with curcubitaceous vegetable, such as melon (Mota et al. 2010).

In this study we investigated the hypothesis that soil water storage variability affects soil water balance reliability and irrigation management, with the objective of evaluate soil water storage variability in the melon root zone; and indicate - based on spatial variation of soil water storage - the region of highest root activity of the melon crop in different development stages.

\section{MATERIALS AND METHODS}

The study was carried out at field at the Federal Institute of Education, Science and Technology of Bahia - IF Baiano, Campus of Senhor do Bonfim-BA (10²6’ 44” S ; 40 08’ 55” W and $532 \mathrm{~m}$ alt). A melon orchard was planted on May 3, 2016, using "Redondo Gaúcho" melon. In the cultivation area, 21 drainage lysimeters were installed, with volume of $1.12 \mathrm{~m}^{3}$, length of $1.4 \mathrm{~m}$, width of $1 \mathrm{~m}$ and depth of $0.8 \mathrm{~m}$. The soil used to fill the lysimeter came from the planting area, and some of its physicalhydraulic characteristics are presented in Table 1.

To induce free drainage, the lysimeters had a $0.1-\mathrm{m}$-thick layer of crushed stone and a 0.1-m-thick layer of washed sand at the bottom, as well as perforated PVC pipes to convey the drained water to taps at the lowest part of the terrain.

Microirrigation was used in the experiment by installing a drip system with KATIF emitters with flow rate of $2.3 \mathrm{~L} \cdot \mathrm{h}^{-1}$, spaced by $0.65 \mathrm{~m}$ between the emitters and $2.7 \mathrm{~m}$ between the lines, using one dripper per plant. After configuration of the irrigation system, the test of water distribution and uniformity was performed following the methodology proposed by Cristiansen (1942), which showed a mean distribution uniformity of 95\%.

Soil water content was monitored inside a lysimeter located in the center of the melon orchard. The lysimeter area was selected to avoid the advection effects suffered by border plants. Soil water content data were collected using Time Domain Reflectometry (TDR100), connected to a CR 800 data logger (Campbell Scientific Inc.). A program was written in BASIClanguage for reading and storage of dielectric constant (ka) values obtained in the 40 TDR probes installed inside the lysimeter. The data were daily collected, in the morning, at two periods: (i) immediately before irrigation; and (ii) 30 min after irrigation. The TDR probes were built at the laboratory with the following characteristics: three stainless-steel rods with diameter of $0.003 \mathrm{~m}$, effective length of 0.1 m outside the resin and spaced by $0.017 \mathrm{~m}$; 50 -ohm coaxial cables; 0.05 -m-long layer of polyester resin at the beginning of the rods.

The calibration equation of the probes was obtained based on the adjustment of the apparent (ka measured by TDR in relation to the soil water content $(\theta)$. For this, soil sample was collected in the experimental area. The soil was air-dried, sieved (2-mm screen) and stored in a PVC pipe

Table 1. Soil water retention, soil density (ds) and soil textural classification.

\begin{tabular}{|c|c|c|c|c|c|c|c|c|}
\hline \multirow{2}{*}{ Layer } & \multicolumn{6}{|c|}{ Pressure Head (m) x Water Content $\left(\mathrm{cm}^{3} \mathrm{~cm}-3\right)$} & \multirow{2}{*}{$\begin{array}{c}\mathrm{ds} \\
\left(\mathrm{kg} \mathrm{dm}^{3}\right)\end{array}$} & \multirow{2}{*}{$\begin{array}{c}\text { Texture } \\
\text { classification }\end{array}$} \\
\hline & $0.6 \mathrm{~m}$ & $1 \mathrm{~m}$ & $3.3 \mathrm{~m}$ & $30 \mathrm{~m}$ & $50 \mathrm{~m}$ & $150 \mathrm{~m}$ & & \\
\hline $0-0.2 \mathrm{~m}$ & 0.198 & 0.163 & 0.144 & 0.135 & 0.129 & 0.119 & 1.67 & Clayey-sandy \\
\hline $0.2-0.4 m$ & 0.215 & 0.184 & 0.162 & 0.147 & 0.135 & 0.128 & 1.71 & Clayey-sandy \\
\hline
\end{tabular}


(0.15 m-height $\times 0.1 \mathrm{~m}$ - diameter), homogeneously, approaching the soil density to $1.7 \mathrm{~kg} \cdot \mathrm{dm}^{3}$. At the bottom of the PVC pipe, a thin screen with the function of only allowing water to pass through it was installed. The soil was saturated inside the tubes, then the TDR probe was inserted. With the soil in a saturated state, the measurements of PVC pipe + probe + soil + screen weight were initiated, in agreement with the measurements of dielectric constant $(\mathrm{ka})$. Soil water content $(\theta)$ for each weighing was determined by Eq. 1:

$$
\theta=\left(\frac{w_{1}-w_{2}}{w_{2}-w_{3}}\right) \frac{d s}{d w}
$$

where $\theta$ is the soil water content $\left(\mathrm{m}^{3} \cdot \mathrm{m}^{-3}\right) ; \mathrm{w}_{1}$ is the PVC pipe + water + soil + TDR probe + screen weight $(\mathrm{kg}) ; \mathrm{w}_{2}$ is the PVC pipe + soil + TDR probe + screen weight $(\mathrm{kg})$; $\mathrm{w}_{3}$ is the PVC pipe + TDR probe + screen weight $(\mathrm{kg})$; ds is soil density $\left(1700 \mathrm{~kg} \cdot \mathrm{m}^{-3}\right)$; and dw is water density $\left(1000 \mathrm{~kg} \cdot \mathrm{m}^{-3}\right)$.

Equation 2 resulted from the TDR calibration process:

$$
\begin{aligned}
& \theta=6 * 10^{-5} k a^{3}-3.4 * 10^{-3} k a^{2}+ \\
& +7.63 * 10^{-2} k a-0.4234 R^{2}=0.989
\end{aligned}
$$

Irrigation was daily performed and managed based on the soil water content obtained with TDR, considering the water volume necessary to bring the soil to field capacity.

Forty TDR probes were distributed inside the lysimeter in four monitoring profiles: P1, P2, P3, and P4, as illustrated in Fig.1. The profiles P1, P2, P3, and P4 represented the experimental distribution. The different monitoring positions were: $0.18,0.36$, $0.54 \mathrm{~m}$ for the profiles 3 and 4 , while for the profiles 1 and 2 , the positions of the probes were 0.18 and $0.36 \mathrm{~m}$.

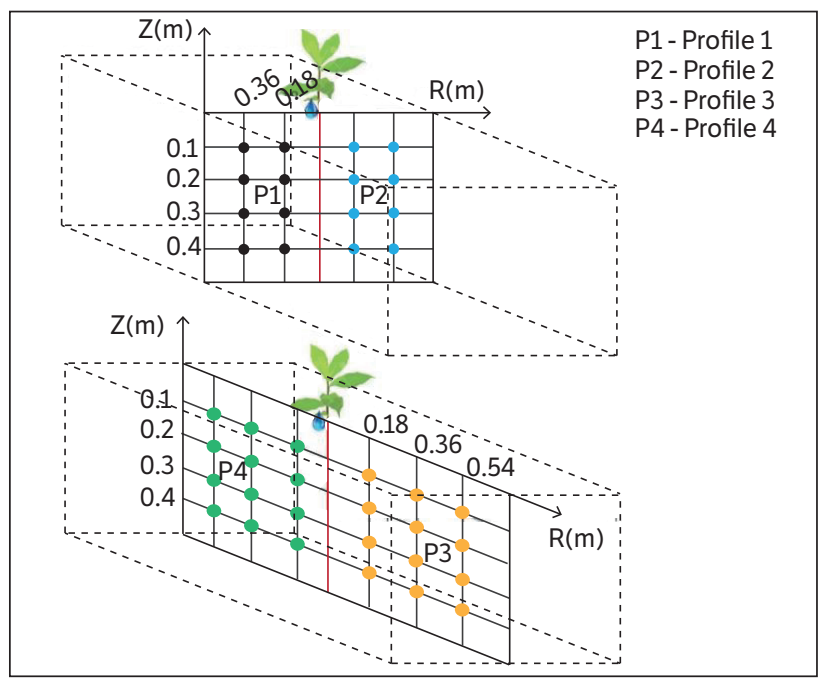

Figure1. Three-dimensional distribution of TDR probes inside thelysimeter.
The replicates were represented by the irrigation events, considering five irrigation events in each development stage of the plant.

The different crop phenological stages were determined based on the methodology proposed by Allen et al. (1998):

I. Initial stage - from planting until $10 \%$ of soil cover (May 10 to May 23, 2016);

II. Vegetative growth $-10 \%$ of soil cover until total cover (May 23 to June 1, 2016);

III. Flowering and fruit growth stage - appearance of first inflorescence until appearance of first fruit (June 1 to June 14, 2016);

IV. Maturation of fruit - appearance of first fruit until fruit maturation (June 14 to July 4, 2016).

The soil water storage variation $(\Delta \mathrm{h})$ in the melon root zone was quantified by Eq. 3, applied to a region of interest in the profile ( $\mathrm{RiZi})$ :

$$
\Delta \mathrm{h}=\frac{\sum_{\mathrm{i}=1}^{\mathrm{n}}\left(\int_{0}^{\mathrm{L}} \theta_{\mathrm{t}+1} \mathrm{dz}-\int_{0}^{\mathrm{L}} \theta_{\mathrm{t} 2} \mathrm{dz}\right)}{\mathrm{n}}
$$

where $\Delta \mathrm{h}$ is the value of soil water storage variation in a region of interest "RiZi" in the soil profile $\left(\mathrm{cm}^{3} \cdot \mathrm{cm}^{-3}\right) ; \theta_{t+1}$ is the soil water content $30 \mathrm{~min}$ after irrigation in "RiZi"; $\theta t_{2}$ is the value of soil water content immediately before the subsequent irrigation in "RiZi" and Ri and Zi are the limits of distance and depth, respectively; and $\mathrm{n}$ is the number of soil water content monitoring points considered (ranging from 1 to 40$)$.

For each monitoring point, soil water availability was determined based on the values of soil water content at field capacity (pressure head $-1 \mathrm{~m}$ ) and permanent wilting point $(-150 \mathrm{~m})$, through Eq. 4:

$$
A W_{(R i, Z i)}=\left(\frac{\theta_{(R i, Z i)}-\theta_{p w p}}{\theta_{f c}-\theta_{p w p}}\right)
$$

where $\mathrm{AW}_{(\mathrm{Ri}, \mathrm{Zi})}$ is the soil water availability (\%) in one point "RiZi" of the soil profile; $\theta_{(\mathrm{Ri}, \mathrm{Zi})}$ is the actual soil water content in "RiZi"; $\left(\mathrm{m}^{3} \cdot \mathrm{m}^{-3}\right) ; \theta_{\text {pwp }}$ is the soil water content referring to the permanent wilting point and $\theta_{\mathrm{fc}}$ is the soil water content referring to the field capacity.

The variability of soil water storage in the melon root zone was obtained according to the different soil water content 
monitoring positions and time, measured based on the values of coefficient of variation, following the criteria proposed by Warrick and Nielsen (1980), which consider the variability as low when $\mathrm{CV}<12 \%$, medium when $12 \%<\mathrm{CV}<60 \%$ and high when $\mathrm{CV} \geq 60 \%$.

In each melon development stage, a descriptive analysis of the soil water storage data was performed based on the values of mean, coefficient of variation, asymmetry and kurtosis, calculated for the four profiles and the six irrigation events.

\section{RESULTS AND DISCUSSION Soil water storage $(\Delta h)$ variation in the melon root zone}

Figure 2 shows the differences of $\Delta \mathrm{h}$ variation in the profiles with changes in the melon crop stages. $\Delta \mathrm{h}$ was $>0$ in the layers (Z-0.1 to Z-0.3 m) for all development stages of the melon crop. The highest intensity of $\Delta \mathrm{h}$ occurs in the flowering and fruit growth stage. For the initial development stage, the mean daily values of $\Delta \mathrm{h}$ ranged from

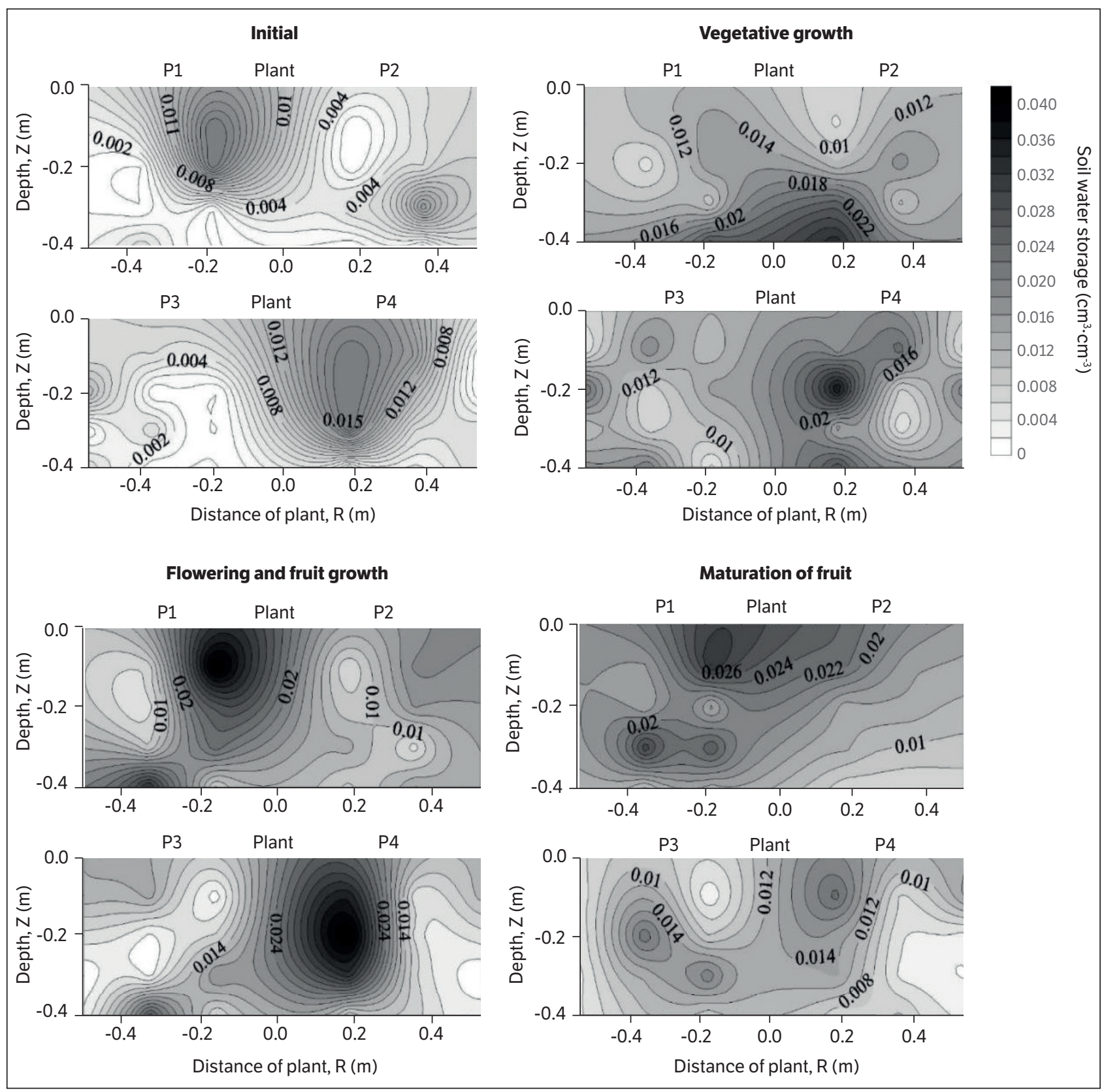

Figure 2. Three-dimensional distribution of soil water storage $\left(\mathrm{cm}^{3} \cdot \mathrm{cm}^{-3}\right)$ in the root zone of irrigated melon in different development stages. 
$5 \times 10^{-3} \mathrm{~cm}^{3} \cdot \mathrm{cm}^{-3}$ to $0.02 \mathrm{~cm}^{3} \cdot \mathrm{cm}^{-3}$ in the most superficial soil layer: Z-0.1 $\mathrm{m}$ (means obtained with all radial distances). In the layer Z-0.1 m, in the stages of vegetative growth, flowering and fruit growth and maturation of fruit, the mean values of soil water storage were $0.004 \mathrm{~cm}^{3} \cdot \mathrm{cm}^{-3}$ to $0.023 \mathrm{~cm}^{3} \cdot \mathrm{cm}^{-3}$, $0.005 \mathrm{~cm}^{3} \cdot \mathrm{cm}^{-3}$ to $0.042 \mathrm{~cm}^{3} \cdot \mathrm{cm}^{-3}$ and $0.004 \mathrm{~cm}^{3} \cdot \mathrm{cm}^{-3}$ to $0.032 \mathrm{~cm}^{3} \cdot \mathrm{cm}^{-3}$, respectively.

Despite the increase in soil water storage over time, there was no percentage increase of soil water storage in the superficial layer for the other stages, indicating the increase of root activity in subsurface even in the flowering stage. The percentage values of water outflow observed in the layer
Z-0.1 $\mathrm{m}$ in relation to the total of the profile were $42.25 \%$, $20.85 \%, 27.43 \%$ and $31.91 \%$ in the initial, vegetative growth, flowering and fruit growth stages, respectively.

There was an increase of $4.48 \%$ in uptake in the superficial layer for the fruit growth stage, indicating that the soil water storage activity occurs mostly in the layer Z-0.1 m for the melon crop under the studied conditions. In the vegetative growth stage, there was also an uptake activity in the layer Z-0.4 m, which can be attributed to the outflows through percolation inside the lysimeter, with a percentage value of $33.64 \%$ in relation to the total.

The values shown in Fig. 3 are mean contents of available water in the soil obtained in the same irrigation events, used to

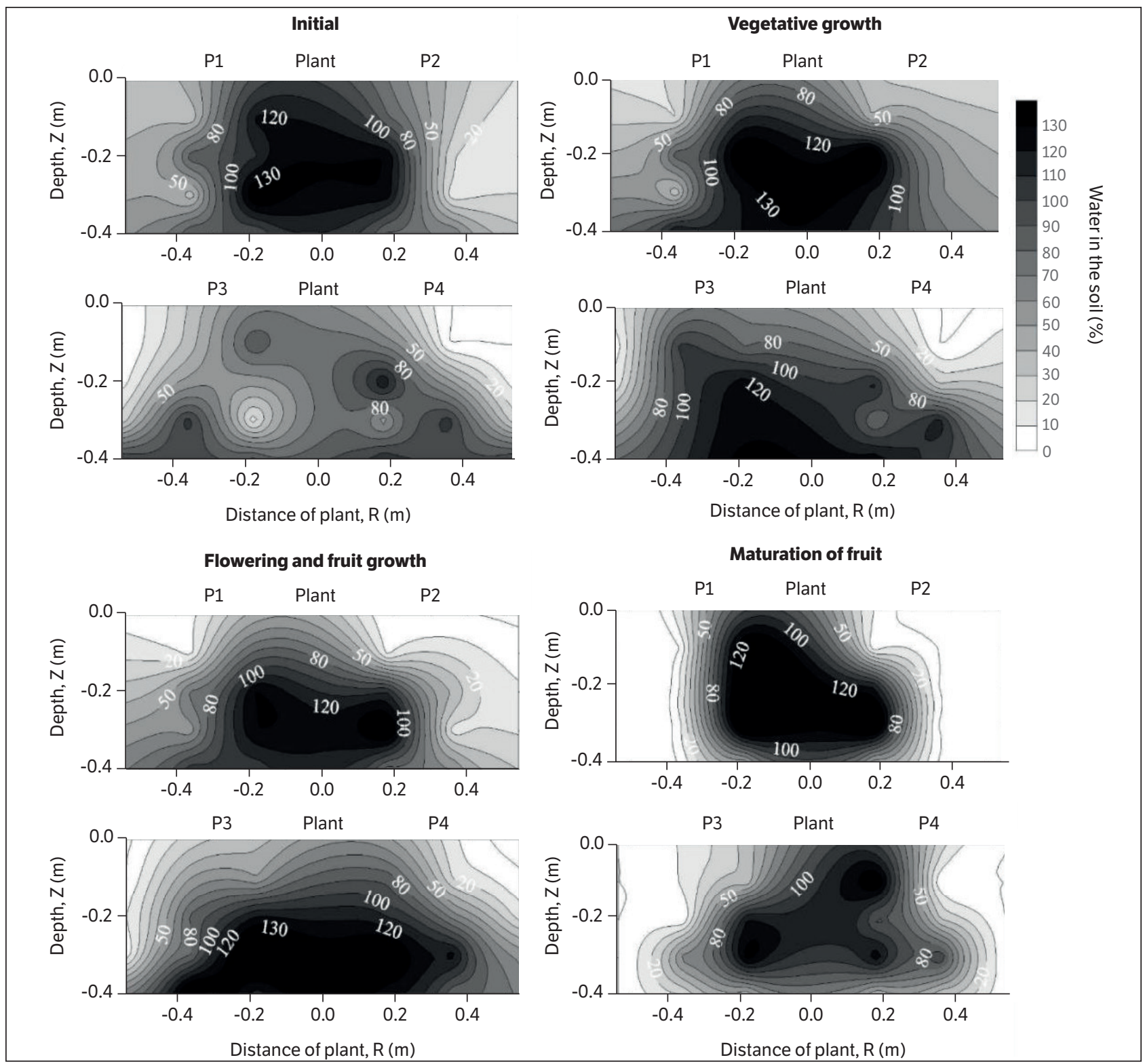

Figure 3. Distribution of soil water availability (\%) inside the lysimeter 30 minutes after irrigation for the different development stages of the melon crop. 
calculate the values of soil water storage presented in Fig. 2. The contents of available water in the most superficial soil layer are always close to $100 \%$, indicating the adequacy of the irrigation management based on water storage variation in the melon root zone, because the replacement of water to the soil is calculated as a function of the integration of the water volume necessary to bring soil moisture back to field capacity in each TDRmonitored point.

It is possible to observe that the water distribution in the superficial layers occurs at an approximate distance of $0.25 \mathrm{~m}$ from the plant, forming a wet bulb with diameter of $0.5 \mathrm{~m}$. Such water distribution is attributed to the emitter used, which irrigates only $14.02 \%$ of the area occupied by the plant.

Based on the coefficients of variation obtained with the values of the available water variability that generated Fig. 3, the variability of the available water contents after irrigation can be considered as high, in all evaluated soil layers (Table 2). The coefficients of variation obtained with the results of soil water storage variability that generated Fig. 2 are high, especially in the layer Z-0.1 m, where the highest uptake occurred in all crop stages.

The water uptake in the melon root zone was not proportional to the soil water availability, which is different from the results obtained by Coelho et al. (2010), Soulis et al. (2015) and Soulis and Elmaloglou (2016), indicating that application of water by irrigation system does not direct influence on soil water storage variation by melon crop. Silva et al. (2015) already observed that the variability of soil water storage in the banana root zone does not have a well-defined relationship with water availability.

\section{Percent distribution of the total soil water storage in layers of the soil profile}

Table 3 shows the results of the descriptive statistics for the percentage values of soil water storage in the zone of root activity of the melon crop, quantified at different monitoring positions in six irrigation events, in each of the crop development stages. The values in percent variation of soil water storage were considered as medium to high, following the classification criteria proposed by Warrick and Nielsen (1980).

Based on the criteria proposed by Jones (1969) to accept the hypothesis that a sample with 24 values follows normal distribution ( 4 profiles $\times 6$ irrigations), the threshold values of asymmetry (G1) and kurtosis (G2) of the data set of soil water storage percentage obtained inside the lysimeter in each monitoring position ( $\mathrm{Rn}, \mathrm{Zn}$ ) are $-0.96 \leq \mathrm{G} 1 \leq 0.96$ and $-1.20 \leq \mathrm{G} 2 \leq 2.32(\mathrm{n}=24)$. Since the probes installed at a distance of $0.54 \mathrm{~m}$ from the plant only appear in two profiles, the values of asymmetry (G1) and kurtosis (G2) were conditioned to 12 results ( 2 profiles $\times 6$ irrigations), and G1 varied from -1.278 to 1.278 , while $\mathrm{G} 2$ varied from -1.56 to 3.12. Based on the percentage values of soil water storage by the melon crop at distance $\mathrm{R}$ from the plant and depth Z, it is observed that not all values follow normal distribution.

\section{Recommendation of the effective region of soil water storage in the melon root zone.}

Although there was difference in the intensity of soil water storage variation by the melon root system in the layers over time, due to increase in water demand by the crop during its growth, the percent distribution of soil water storage in the

Table 2. Coefficients of variation (\%) for the radial distribution of soil water storage variation $(\Delta \mathrm{h})$ and soil water availability (SWA) in the melon crop at different soil depths.

\begin{tabular}{|c|c|c|c|c|c|c|c|c|}
\hline \multirow{4}{*}{$\begin{array}{l}\text { Soil Depth } \\
\text { (m) }\end{array}$} & \multicolumn{8}{|c|}{ Melon development stage } \\
\hline & \multicolumn{2}{|c|}{ Initial } & \multicolumn{2}{|c|}{ Vegetative growth } & \multicolumn{2}{|c|}{ Flowering and Fruit growth } & \multicolumn{2}{|c|}{ Mature of fruit } \\
\hline & $\Delta \mathbf{h}$ & SWA & $\Delta \mathbf{h}$ & SWA & $\Delta \mathbf{h}$ & SWA & $\Delta \mathbf{h}$ & SWA \\
\hline & \multicolumn{8}{|c|}{ Coefficient of Variation (\%) } \\
\hline 0.10 & 122.50 & 92.20 & 47.70 & 83.80 & 110.80 & 101.60 & 61.30 & 173.40 \\
\hline 0.20 & 125.90 & 74.50 & 62.20 & 53.70 & 92.00 & 57.60 & 52.50 & 116.20 \\
\hline 0.30 & 124.60 & 81.50 & 53.00 & 55.70 & 71.00 & 64.30 & 70.60 & 90.50 \\
\hline 0.40 & 141.40 & 12.00 & 43.10 & 51.50 & 55.40 & 31.90 & 33.90 & 90.50 \\
\hline
\end{tabular}

$\Delta \mathrm{h}$ - Soil water storage variation; SWA - soil water availability (\%). 
profiles does not vary as much as the intensity of soil water storage over time. This fact demonstrates that the temporal variability of water storage by the melon crop is greater than the spatial variability. A similar result was found by Silva et al. (2015), evaluating the variability of soil water storage by the root system of banana under micro-sprinkler irrigation.

Table 4 shows the mean percentage values and their standard deviations for the region delimited by the effective soil water storage in distance from the plant and depth, in all development stages. In the initial development stage, $86.56 \%$ of the water extracted in the profiles occurred until the layer of Z-0.3 m. The same occurs for the vegetative growth and the flowering and fruit growth stages, and the uptakes were respectively equal to $75.76,77.06$ and $70.34 \%$. Considering as the region of highest water outflow intensity the one whose minimum limit of the total water extracted in distance and depth is $70 \%$, the ideal region to install sensors and apply nutrients in the melon root zone is comprehended between R-0.36 $\mathrm{m}$ from the plant and Z-0.3 $\mathrm{m}$ of depth.

Table 3. Descriptive statistics for the percentage soil water storage in the region explored by melon roots at each soil monitoring positions (\%), relative to four profiles and six irrigation events in each melon development stage.

\begin{tabular}{|c|c|c|c|c|c|c|c|c|c|c|c|}
\hline \multirow{2}{*}{$\underset{(m)}{R}$} & $\mathbf{x}$ & (S) & CV & \multirow{2}{*}{ G1 } & \multirow{2}{*}{ G2 } & \multirow{2}{*}{$\underset{(m)}{Z}$} & $\mathbf{x}$ & (S) & CV & \multirow{2}{*}{ G1 } & \multirow{2}{*}{ G2 } \\
\hline & \multicolumn{3}{|c|}{$\%$} & & & & \multicolumn{3}{|c|}{$\%$} & & \\
\hline \multicolumn{12}{|c|}{ INITIAL } \\
\hline 0.18 & 39.90 & 34.53 & 86.54 & 0.38 & 1.48 & 0.10 & 34.12 & 33.96 & 99.52 & 0.52 & 0.99 \\
\hline 0.36 & 41.21 & 33.96 & 82.41 & 0.92 & 1.26 & 0.20 & 20.54 & 16.75 & 81.53 & -0.10 & 0.96 \\
\hline \multirow[t]{2}{*}{0.54} & 45.53 & 33.45 & 73.48 & 1.19 & 2.24 & 0.30 & 22.83 & 29.38 & 128.71 & 0.63 & 0.63 \\
\hline & & & & & & 0.40 & 7.60 & 8.92 & 117.33 & 0.75 & 0.45 \\
\hline \multicolumn{12}{|c|}{ VEGETATIVE GROWTH } \\
\hline 0.18 & 47.04 & 15.50 & 32.94 & -0.26 & 0.42 & 0.10 & 24.06 & 16.91 & 70.26 & 0.38 & 0.45 \\
\hline 0.36 & 41.82 & 15.20 & 36.35 & -0.53 & 0.68 & 0.20 & 25.45 & 13.33 & 52.37 & -0.09 & 0.57 \\
\hline \multirow[t]{2}{*}{0.54} & 23.00 & 16.56 & 71.98 & -2.12 & 0.91 & 0.30 & 22.10 & 11.64 & 52.69 & 0.39 & 0.37 \\
\hline & & & & & & 0.40 & 28.73 & 18.47 & 64.28 & 0.62 & 0.63 \\
\hline \multicolumn{12}{|c|}{ FLOWERING AND FRUIT GROWTH } \\
\hline 0.18 & 46.36 & 26.73 & 57.66 & 0.13 & 1.38 & 0.10 & 30.05 & 27.62 & 91.91 & 0.19 & 0.74 \\
\hline 0.36 & 42.92 & 27.66 & 64.43 & 0.53 & 1.55 & 0.20 & 23.05 & 12.59 & 54.61 & 0.05 & 0.49 \\
\hline \multirow[t]{2}{*}{0.54} & 22.08 & 24.97 & 113.09 & -0.51 & 1.19 & 0.30 & 17.11 & 15.14 & 88.47 & 1.37 & 0.49 \\
\hline & & & & & & 0.40 & 18.64 & 24.20 & 129.85 & 0.68 & 0.79 \\
\hline \multicolumn{12}{|c|}{ MATURATION OF FRUIT } \\
\hline 0.18 & 52.24 & 21.16 & 40.50 & -0.55 & 0.61 & 0.10 & 29.25 & 20.82 & 71.20 & 0.95 & 0.88 \\
\hline 0.36 & 42.31 & 21.07 & 49.81 & 0.34 & 0.65 & 0.20 & 34.85 & 52.09 & 149.49 & 0.93 & 0.44 \\
\hline \multirow[t]{2}{*}{0.54} & 20.21 & 14.20 & 70.25 & -1.57 & 0.67 & 0.30 & 24.60 & 12.87 & 52.29 & 0.68 & 0.46 \\
\hline & & & & & & 0.40 & 18.17 & 12.33 & 67.87 & 0.59 & 0.37 \\
\hline
\end{tabular}

R- Radial distance from the plant; Z - Soil Depth; CV - Coefficient of variation; G1 - Asymmetry; G2 - Kurtosis; S - Standard deviation; X-average.

Table 4. Limits of maximum distance and depth of the effective soil water storage activity by the melon crop in different development stages.

\begin{tabular}{ccccccc}
$\begin{array}{c}\text { Vegetative } \\
\text { development stage }\end{array}$ & $\begin{array}{c}\text { Maximum distance from } \\
\text { the melon plant }(\mathbf{m})\end{array}$ & $\mathbf{X}(\%)$ & $\mathbf{s}$ & $\begin{array}{c}\text { Maximum depth } \\
(\mathbf{m})\end{array}$ & $\mathbf{X}(\%)$ \\
\hline Initial & 0.36 & 80.98 & 2.95 & 0.30 & 86.56 & 39.44 \\
\hline Vegetative growth & 0.36 & 76.24 & 21.14 & 0.30 & 75.76 & 15.64 \\
\hline Flowering and fruit growth & 0.36 & 78.94 & 21.40 & 0.30 & 77.06 & 30.94 \\
\hline Maturation of fruit & 0.36 & 77.05 & 26.45 & 0.30 & 70.34 & 23.11 \\
\hline
\end{tabular}

$\mathrm{X}(\%)$ - means; S - Standard deviation. 
Considering that the soil volume for the determination of water balance in melon and other cucurbits is arbitrarily chosen (Mota et al. 2010; Monteiro et al. 2013), the results found in the present study also serve to indicate the monitoring volume of water balance, allowing to control the moisture where the root system has higher activity.

\section{CONCLUSIONS}

The soil water storage variation in the melon root zone occurs with greater intensity throughout the time of vegetative growth and the highest values are always observed in the same distances and depths of the soil in all phases of growth.

The region indicated as of greatest root activity of the melon crop under drip irrigation is delimited, in relation to the stem, by the radial distance of $0.36 \mathrm{~m}$ and depth of $0.3 \mathrm{~m}$, for all of its development stages.

\section{AUTHORS' CONTRIBUTION}

Conceptualization, Nascimento F. A. L., Silva, A. J. P and Campos, A. R. F.; Methodology, Nascimento F. A. L., Silva, A. J. P. and Campos, A. R. F; Investigation, Nascimento F. A. L., Silva, A. J. P and Campos, A. R. F.; Writing - Nascimento F. A. L., Silva, A. J. P and Campos, A. R. F; Resources; Nascimento F. A. L., Silva, A. J. P.; Supervision, Nascimento F. A. L. and Silva, A. J. P.

\section{ORCID IDS}

\author{
F.A.L. Nascimento \\ (iD https://orcid.org/0000-0002-5018-8529 \\ A.J.P. Silva \\ (iD) https://orcid.org/0000-0002-1720-4216 \\ A.R.F. Campos \\ iD https://orcid.org/0000-0001-7057-8359
}

\section{REFERENCES}

Allen, R. G., Pereira, L. S., Raes, D. and Smith, M. (1998). Crop evapotranspiration - Guidelines for computing crop water requirements - FAO Irrigation and drainage paper 56. FAO, 300, D05109. https://appgeodb.nancy.inra.fr/biljou/pdf/Allen_FAO1998. pdf

Coelho, E. F., Silva, A. J. and Miranda, J. H. D. (2010). Sensor placement for soil water monitoring in banana crop irrigated by drip irrigation systems. Engenharia Agrícola, 30, 608-618. https:// doi.org/10.1590/S0100-69162010000400005

Christiansen, J. E. (1942). Irrigation by Sprinkling. California Agricultural Experimental Station Bulletin 670. Berkeley: University of California.

Dabach, S., Shani, U. and Lazarovitch, N. (2016). The influence of water uptake on matric head variability in a drip-irrigated root zone. Soil and Tillage Research, 155, 216-224. https://doi.org/10.1016/j. still.2015.08.012

Green, S. R., Kirkham, M. B. and Clothier, B. E. (2006). Root uptake and transpiration: From measurements and models to sustainable irrigation. Agricultural Water Management, 86, 165-176. https://doi. org/10.1016/j.agwat.2006.06.008
Jones, T. A. (1969). Skewness and kurtosis as criteria of normality in observed frequency distributions. Journal of Sedimentary Research, 39, 1622-1627. https://doi. org/10.1306/74D71EC9-2B21-11D7-8648000102C1865D

Lucas, A. A. T., Frizzone, J. A. and Coelho Filho, M. A. (2012). Características da distribuição radicular de maracujazeiro sob fertirrigação. Irriga, 17, 245-250. https://doi.org/10.15809/ irriga.2012v17n2p245

Mota, J. C. A., Libardi, P. L., Brito, A. D. S., Assis Júnior, R. N. D. and Amaro Filho, J. (2010). Armazenagem de água e produtividade de meloeiro irrigado por gotejamento, com a superfície do solo coberta e desnuda. Revista Brasileira de Ciência do Solo, 34 , 1721-1731. https://doi.org/10.1590/S0100-06832010000500024

Monteiro, R. O. C., Coelho, R. D., Monteiro, P. F. C., Whopmans, J. and Lennartz, B. (2013). Water consumption and soil moisture distribution in melon crop with mulching and in a protected environment. Revista Brasileira de Fruticultura, 35, 555-564. https:// doi.org/10.1590/S0100-29452013000200026

Raza, A., Friedel, J. K., Moghaddam, A., Ardakani, M. R., Loiskandl, W., Himmelbauer, M. and Bodner, G. (2013). Modeling growth of 
different lucerne cultivars and their effect on soil water dynamics. Agricultural water management, 119, 100-110. https://doi. org/10.1016/j.agwat.2012.12.006

Sant'ana, J. D. V., Coelho, E. F., Faria, M. D., Silva, E. D. and Donato, S. L. R. (2012). Distribuição de raízes de bananeira 'Prata-Anã' no segundo ciclo de produção sob três sistemas de irrigação. Revista Brasileira de Fruticultura, 34, 124-132. https://doi.org/10.1590/S0100-29452012000100018

Silva, A. J. P., Coelho, E. F., Coelho Filho, M. A. and Souza, J. L. D. (2018). Water extraction and implications on soil moisture sensor placement in the root zone of banana. Scientia Agricola, 75, 95-101. https://doi.org/10.1590/1678-992x-2016-0339

Silva, A. J. P., Coelho, E. F. and Coelho Filho, M. A. (2015). Water extraction variability in the banana root zone affects the reliability of water balance. Scientia Agricola, 72, 1-10. https:// doi.org/10.1590/0103-9016-2014-0003

Silva, A. J. P., Coelho, E. F., Miranda, J. H. D. and Workman, S. R. (2009). Estimating water application efficiency for drip irrigation emitter patterns on banana. Pesquisa Agropecuária Brasileira, 44, 730-737. https://doi.org/10.1590/S0100-204X2009000700013

Soulis, K. X. and Elmaloglou, S. (2016). Optimum soil water content sensors placement in drip irrigation scheduling systems: concept of time stable representative positions. Journal of Irrigation and Drainage Engineering, 142, 04016054-1-040160549. https://doi.org/10.1061/(ASCE)IR.1943-4774.0001093

Soulis, K. X., Elmaloglou, S. and Dercas, N. (2015). Investigating the effects of soil moisture sensors positioning and accuracy on soil moisture based drip irrigation scheduling systems. Agricultural Water Management, 148, 258-268. https://doi. org/10.1016/j.agwat.2014.10.015

Souza, C. D., Andrade, A. P. D., Lima, J. R. D. S., Antonino, A. C., Souza, E. S. D. and Silva, I. D. F. D. (2013). Water balance of castor bean under rainfed conditions. Revista Brasileira de Engenharia Agrícola e Ambiental, 17, 3-10. https://doi. org/10.1590/S1415-4366201300010000

Warrick, A. W., Nielsen, D. R. (1980). Spatial variability of soil physical properties in the field. In: HILLEL, D. (Ed.). Applications of soil physics (319-344). New York: Academic, 1980.

Zarebanadkouki, M., Kim, Y. X., Moradi, A. B., Vogel, H. J., Kaestner, A. and Carminati, A. (2012). Quantification and modeling of local root water uptake using neutron radiography and deuterated water. Vadose Zone Journal, 11, 3. https://doi. org/10.2136/vzj2011.0196 